\title{
The Importance of Financial Controlling in the Service Systems With Regard to Insurance
}

\author{
Tatjana Kuzmanović \\ MsC, Insurance company “DDOR” Novi Sad, tatjana.kuzmanovic@ddor.co.rs
}

Received (28.12.2018.); Revised (22.01.2019.); Accepted (13.02.2019.)

\begin{abstract}
The financial controlling is a significant feature of support management in business process management and business results. In terms of increasing competition in business, it is necessary that the activity in the service systems takes place with the lowest possible costs with the highest possible satisfaction of employees and business associates. This can be achieved by placing a clear structure of business costs control. On the one hand, it is a precondition that excessive cost reduction is not to endanger the activity itself, and on the other hand, it prevents spending without control from losing to business. Comparison of planned and achieved revenues is the foundation of decision-making for further business. These are the basic postulates of financial controlling.
\end{abstract}

Key words: Financial kontroling, business result, utility systems

\section{INTRODUCTION TO FINANCIAL MANAGEMENT}

The most acceptable definition of controlling is: "Controlling is the navigation process towards economic goals, where managing, definition of position is performed according to the established order and plans monitoring". [1]

Financial controller is business and commercial minded. He cooperates with other functions outside of finance, almost like a consultant does. With his strong network in eg. logistics, production and sales, he will build business plans and define ways to measure and report on the key indicators of it.[12]

The financial controlling is there to facilitate, to the management, the understanding of the three basic reports: the balance sheet, the profit and loss account and the cash flow statement. [2]

Management (various managers, board members, members of auditing or supervisory committees) require additional information that will help them in day-to-day management of resources, in order to direct, oversee and control them. [11]. That is the aim of controlling to provide the most important information to the board management.

Reports used by a financial controller are reports that are primarily complied for accounting purposes, however, these reports have a very important role in the process of informing and making decisions in company management today [5]. Unlike accountants, whose is focus on business to be in line with legal regulations and international standards, the controlling is not defined by the law and the management of the company has the freedom to form it in line with the needs of the company [14].

On the basis of this, it can be concluded that the main goal of financial controlling is that the company operates profitable, that the support of this function controls the costs and strives to increase revenue and that it is in accordance with the predetermined goals of the advances[18] [19] [20] [11].

This suggests that financial control should serve to define the strategy of further development and operational plan.

By regular reporting by the financial controller, the management of the company can react quickly and, in accordance with that, make important decisions that the company will return to the right path, the path of good business, meeting the set goas and making profit.Due to their being less freqent, and since they are stringlently prescribed and brief in form, they do not satisfy all the needs of the company management for information. Common to these two functions is to use the same data, but in a different way and for different purposes [19] [21] [22] [23].

The introduction of controling in the company involves a series of interconnected and conditioned activities and requires a clearly defined order of steps, but also close cooperation with:

1. the management (interested management, who understands finances and business processes, and can be competent to use the information obtained); 
2. the accounting (direct and internal, not only to external users);

3. IT - Informatics Support (adequate information system tailored to the business of company which enables the obtaining of sufficient relevant data in the satisfactory period of time).

This research indicates that well-organized and set controling reduces business risks in the modern world. The purpose and basic goal that should be fulfilled by the controlling model in the service systems is to enable the management to manage business processes and achieve business results based on the realization of the planned business goals, while excluding the possibility of making subjective decisions by the management.

The aim of this paper is, based on theoretical knowledge, standards and experiences in practice, and results of practical research, to give the appropriate model and recommendations for the improvement of the function and process of financial control in service systems to manage better the business result. In order for the controller to efficiently manage management, it is necessary that the financial controlling function be adequately defined, organized and placed in the Organization, and also that the processes of controlling themselves are established in a quality way.

The research was carried out on a sample of 120 examinees extracted from the population, divided into 4 subsamples, from various types of service activities: banking, insurance, trade and other services [9] [10].

Based on the results of a concrete research conducted in the period november - december 2018 in the service systems in Serbia, in which there were $40.8 \%$ of respondents in the field of insurance, it is possible to use adequate recommendations to improve the most important tasks of financial controlling, and in general controlling - planning, analysing and reporting - also provide better management processes and a better business result of companies.

\section{ANALYSIS OF RESPONDENTS ON THE IMPORTANCE OF FINANCIAL CONTROLLING IN RELATION TO ACTIVITIES}

Within the specified research analysed the opinions of respondents about the importance of financial controlling in relation to the type of service activity, which are expressed through numerical (n) and percentage representation (\%) in relation to the activity.

The research covered questions on the importance of financial controlling: the importance of the interaction between managers and financial controllers, the common defining objectives by managers and controllers, the contribution of financial controlling to better business, the importance of rewards and motivation, the importance of training and educations, implementation of financial controlling and identification of business risks, with a analysis of the impact on a business result of the company.
Table 1. The importance of the interaction between managers and financial controllers in relation to activities

\begin{tabular}{|l|l|l|l|l|l|l|}
\hline & \multicolumn{2}{|l|}{$\begin{array}{l}\text { completely } \\
\text { disagree }\end{array}$} & \multicolumn{2}{|c|}{\begin{tabular}{l}
\multicolumn{2}{c|}{ partly } \\
agree
\end{tabular}} & \multicolumn{2}{c|}{\begin{tabular}{c}
\multicolumn{2}{c|}{ completely } \\
agree
\end{tabular}} \\
\hline & $\mathrm{n}$ & $\%$ & $\mathrm{n}$ & $\%$ & $\mathrm{n}$ & $\%$ \\
\hline services & 9. & $33.3^{\prime \prime}$ & 6. & 22.2 & 12. & 44.4 \\
\hline banking & 9. & 33.3 & 10. & 37.0 & 8. & 29.6 \\
\hline $\begin{array}{l}\text { insuranc } \\
\text { e }\end{array}$ & 3. & 6.1 & 21. & $\begin{array}{l}42.9 \\
*\end{array}$ & 25. & 51.0 \\
\hline trade & 6. & $35.3^{*}$ & 6. & 35.3 & 5. & 29.4 \\
\hline
\end{tabular}

By looking at the data displayed in the table 1. relating to the importance of interaction and cooperation between managers and financial controllers, it is possible to note that the most responsive answer is "I completely agree" in subsample of "services", which consist of 12 respondents (44.4\%) of the total of 27 , while in "insurance" the representation of the answer "I completely agree" (25 respondents, 51.0\%) is significantly higher, followed by a subsample of "services" that consists of 12 respondents (44.4\%) of a total of 27 . The presence of answer „I completely disagree" is the lowest at insurance (6.1\%).

It is important to mention a many advantages that the company has after introducing or improvement of the controlling, and some of them are better informing of management about conditions in and outside the organization, better communication within the organization, more efficient use of accounting information.

The higher the cooperation between the managers and the financial controllers, the better basis is created that affects the making of timely decisions. Employees will easily accept changes that bring Introducing and improvement of the existing controlling. In this sense, it is very significant and common defining objectives by managers and controllers.

Table 2. Common definition of the objectives of the controller manager in relation to the activity

\begin{tabular}{|l|c|c|c|r|r|r|}
\hline & \multicolumn{2}{|c|}{$\begin{array}{l}\text { I completely } \\
\text { disagree }\end{array}$} & \multicolumn{2}{c|}{$\begin{array}{c}\text { I partly } \\
\text { agree }\end{array}$} & \multicolumn{2}{c|}{$\begin{array}{c}\text { completely } \\
\text { agree }\end{array}$} \\
\hline & $\mathrm{n}$ & $\%$ & $\mathrm{n}$ & $\%$ & $\mathrm{n}$ & $\%$ \\
\hline services & 6. & $22.2^{\prime \prime}$ & 7. & $25.9^{\prime \prime}$ & 14. & 51.9 \\
\hline banking & 9. & $33.3^{*}$ & 4. & 14.8 & 14. & 51.9 \\
\hline insurance & 0. & .0 & 5. & 10.2 & 44. & $89.8^{*}$ \\
\hline trade & 2. & 11.8 & 5. & $29.4^{*}$ & 10. & 58.8 \\
\hline
\end{tabular}

By looking at the data displayed in the table 2. it is possible to note that the in the field of insurance, the most represented positive response $(89.8 \%)$, which is significantly higher than other activities.

Very similar conclusions were reached through the opinions of the respondents relating to the contribution of financial controlling in the planning process and business operations (table 3 ): 
Table 3. Contribution of financial controlling in relation to activities

\begin{tabular}{|l|r|r|r|r|r|r|}
\hline & \multicolumn{2}{|c|}{$\begin{array}{c}\text { I completely } \\
\text { disagree }\end{array}$} & \multicolumn{2}{c|}{$\begin{array}{c}\text { I partly } \\
\text { agree }\end{array}$} & \multicolumn{2}{c|}{$\begin{array}{c}\text { I completely } \\
\text { agree }\end{array}$} \\
\hline & $\mathrm{n}$ & $\%$ & $\mathrm{n}$ & $\%$ & $\mathrm{n}$ & $\%$ \\
\hline services & 7. & $25.9^{\prime \prime}$ & 3. & 11.1 & 17. & 63.0 \\
\hline banking & 10. & $37.0^{*}$ & 5. & 18.5 & 12. & 44.4 \\
\hline insurance & 0. & .0 & 5. & 10.2 & 44. & $89.8^{*}$ \\
\hline trade & 4. & 23.5 & 1. & 5.9 & 12. & $70.6^{\prime \prime}$ \\
\hline
\end{tabular}

Education is very important, as well as the system of rewarding and motivating employees, with the request of modern business to continuously improve and refresh professional knowledge.

Training of employees is realized through various professional trainings and seminars, which are adapted to jobs and workplaces, and training of interpersonal skills that support the development of business competences. Attention is devoted to improving the knowledge of foreign languages, as well as the improvement of information knowledge.

For development and implementation of controling is very important to learn how to apply knowledge from controlling in the field of finance, which confirms our research results in tables 4. and 5. Respondents in the field of insurance (55\% for the importance of education, $91.8 \%$ for the importance of motivation) and banking $(63 \%$ for the importance of education, $81.5 \%$ for the importance of motivation) occupy a significant place with the answers "I completely agree".

Table 4. Representation of the impotance of training and education in relation to the activities

\begin{tabular}{|l|r|r|r|r|r|r|}
\hline & \multicolumn{2}{|c|}{$\begin{array}{c}\text { I completely } \\
\text { disagree }\end{array}$} & \multicolumn{2}{c|}{$\begin{array}{c}\text { I partly } \\
\text { agree }\end{array}$} & \multicolumn{2}{c|}{$\begin{array}{c}\text { completely } \\
\text { agree }\end{array}$} \\
\hline & $\mathrm{n}$ & $\%$ & $\mathrm{n}$ & $\%$ & $\mathrm{n}$ & $\%$ \\
\hline services & 1. & 3.7 & 15. & 55.6 & 11. & 40.7 \\
\hline banking & 1. & 3.7 & 9. & 33.3 & 17. & 63.0 \\
\hline insurance & 3. & 6.1 & 19. & 38.8 & 27. & 55.1 \\
\hline trade & 3. & 17.6 & 6. & 35.3 & 8. & 47.1 \\
\hline
\end{tabular}

When talking about advancement of business, the research has determined the importance of risk identification that can be applied and implemented into their business to reduce a possibility of occurence risk event. However, this is not a guarantee that the risk itself will not happen, but it is only an investment in prevention, ie, reducing the possibility of Achievements achieving a certain risky situation. Only risk management is of special importance in the planning or the actual realization of business processes.
Table 5. The importance of rewards and motivation in relation to the activities

\begin{tabular}{|l|r|r|r|r|r|r|}
\hline & \multicolumn{2}{|c|}{$\begin{array}{c}\text { I completely } \\
\text { disagree }\end{array}$} & \multicolumn{2}{c|}{$\begin{array}{c}\text { I partly } \\
\text { agree }\end{array}$} & \multicolumn{2}{c|}{$\begin{array}{c}\text { completely } \\
\text { agree }\end{array}$} \\
\hline & $\mathrm{n}$ & $\%$ & $\mathrm{n}$ & $\%$ & $\mathrm{n}$ & $\%$ \\
\hline services & 0. & .0 & 11. & $40.7^{*}$ & 16. & 59.3 \\
\hline banking & 1. & 3.7 & 4. & 14.8 & 22. & $81.5^{\prime \prime}$ \\
\hline insurance & 0. & .0 & 4. & 8.2 & 45. & $91.8^{*}$ \\
\hline trade & 1. & $5.9^{*}$ & \multicolumn{1}{|c|}{3.} & 17.6 & 13. & 76.5 \\
\hline
\end{tabular}

By looking at the data in table 7 , it can be found that respondents in the field of insurance (83.7\%) and banking (74.1\%) have the most represented answer "I completely agree", which fully corresponds to the risky and dynamic nature of the jobs that those activities are exposed to.

Table 6. Identification of business risk in relation to activities

\begin{tabular}{|l|r|r|r|r|r|r|}
\hline & \multicolumn{2}{|c|}{$\begin{array}{c}\text { I completely } \\
\text { disagree }\end{array}$} & \multicolumn{2}{c|}{$\begin{array}{c}\text { I partly } \\
\text { agree }\end{array}$} & \multicolumn{2}{c|}{$\begin{array}{c}\text { I completely } \\
\text { agree }\end{array}$} \\
\hline & $\mathrm{n}$ & $\%$ & $\mathrm{n}$ & $\%$ & $\mathrm{n}$ & $\%$ \\
\hline services & 1. & 3.7 & 8. & 29.6 & 18. & 66.7 \\
\hline banking & 1. & 3.7 & 6. & 22.2 & 20. & 74.1 \\
\hline insurance & 1. & 2.0 & 7. & 14.3 & 41. & $83.7^{*}$ \\
\hline trade & 1. & 5.9 & 7. & $41.2^{*}$ & 9. & 52.9 \\
\hline
\end{tabular}

Table 7. Significance of the difference between the activity of respondents in relation to question about financial controlling Legend: $k . d s k$ is the coefficient of discrimination

\begin{tabular}{|c|c|c|c|c|c|}
\hline & $\chi$ & $\mathrm{R}$ & $\mathrm{F}$ & $p$ & k.dsk \\
\hline $\begin{array}{l}\text { Importance of } \\
\text { the interaction of } \\
\text { managers and } \\
\text { financial } \\
\text { controllers }\end{array}$ & .329 & .326 & 4.653 & .004 & .068 \\
\hline $\begin{array}{l}\text { Common } \\
\text { defining } \\
\text { objectives by } \\
\text { manager and } \\
\text { controllers }\end{array}$ & .415 & .423 & 8.490 & .000 & .020 \\
\hline $\begin{array}{l}\text { Contribution to } \\
\text { financial } \\
\text { controlling }\end{array}$ & .401 & .426 & 8.651 & .000 & .058 \\
\hline $\begin{array}{l}\text { Importance of } \\
\text { rewarding and } \\
\text { motivating }\end{array}$ & .347 & .325 & 4.603 & .004 & .067 \\
\hline $\begin{array}{l}\text { Importance of } \\
\text { training and } \\
\text { aducation }\end{array}$ & .238 & .187 & 1.418 & .241 & .048 \\
\hline $\begin{array}{l}\text { Implementation } \\
\text { of financial } \\
\text { controlling }\end{array}$ & .246 & .202 & 1.659 & .180 & .055 \\
\hline $\begin{array}{l}\text { Identification of } \\
\text { business risk }\end{array}$ & .234 & .240 & 2.386 & .073 & .030 \\
\hline
\end{tabular}


3. ANALYSIS OF DIFFERENCES BETWEEN ACTIVITIES OF RESPONDENTS IN RELATION TO THE QUESTION ABOUT THE IMPORTANCE OF FINANCIAL CONTROLLING

With the application of discriminatory methods on the observed sample, it can be prove or reject the assertion that there is a significant difference between the activities of the respondents, in relation to question about the importance of financial controlling.

The coefficient of discrimination indicates that the greatest contribution is to discrimination between the activity of respondents in relation to the question about the importance of financial controlling, i.e. the highest difference can be found: at importance of the interaction between the managers and financial controllers (.068), the importance of rewards and motivation (. 067), the contribution of financial controlling (. 058), implemention of financial controlling (. 055), the importance of training and education (. 048), identification of business risk (. 030), common defining of objectives by managers and controllers (. 020).

A latent feature is a feature in which no distinction is made between activities and the discriminatory analysis has included it in the structure in which there is a significant difference between the activities. Latent characteristics have: the importance of training and education (. 241) and the implementation of financial Controlling (. 180).

\section{CHARACTERISTICS OF THE ACTIVITIES OF RESPONDENTS IN RELATION TO QUESTIONS ABOUT THE IMPORTANCE OF FINANCIAL CONTROLLING AND GRAPHICAL VIEW}

By Calculating the Mahalanobis distance between the activities of respondents, another indicator of similarity or difference is obtained.

Table 8. Distance (Mahalanobis) between activities of respondents in relation to the question about the importance of financial controlling

\begin{tabular}{|l|r|r|r|r|}
\hline & Services & Banking & Insurance & Trade \\
\hline Services & .00 & .98 & 1.12 & 1.18 \\
\hline Banking & .98 & .00 & 1.26 & 1.41 \\
\hline Insurance & 1.12 & 1.26 & .00 & 1.21 \\
\hline Trade & 1.18 & 1.41 & 1.21 & .00 \\
\hline
\end{tabular}

The distance of different activities can be compared. The distance from the table 8 . indicates that the least distance is between the business: banking and services (.98) (moderate) and the farthest are the activities of the respondents: trade and banking (1.41) (higher).

Table 9. Grouping of activities of respondents in relation to the question about the importance of financial controlling

\begin{tabular}{|c|c|}
\hline level & proximity \\
\hline services - banking & .98 \\
\hline Insurance - trade & 1.21 \\
\hline service - insurance & 1.30 \\
\hline
\end{tabular}

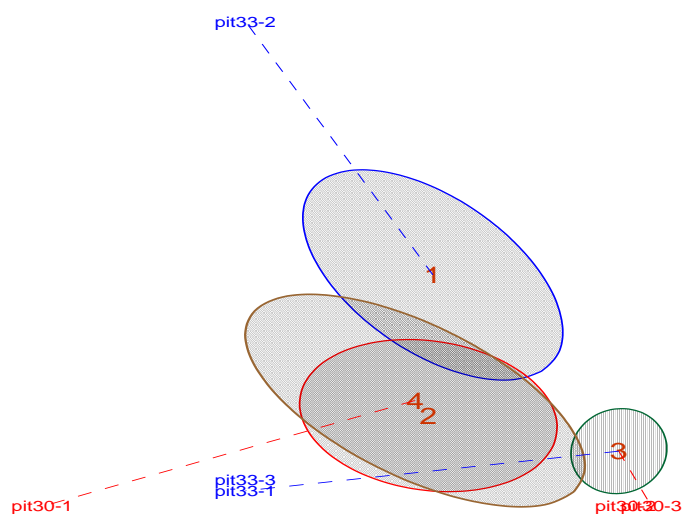

Figure 1. Elipse of activities of respondents in relation to the importance of the interaction between managers and financial controllers and significant rewards and motivation. Legend: services (1); banking (2); insurance (3); trade (4); I completely disagree; I partly agree.

Apscisa (horizontal axis) shows the significance of the interaction between managers and financial controllers that is represented by a 3-step scale, and the ordinate (vertical axis) shows the importance of reward and motivation that is presented with a 3-step scale.

By looking at figure 1. it can be noticed that in the importance of interaction between managers and financial controllers and the importance of rewarding and motivating, the ellipses of business activity Banking (2) and Trade (4) overlap or have similar characteristics.

Apscisa (horizontal axis) shows the significance of the interaction between managers and financial controllers that is presented with a 3-step scale, and the ordinate (vertical axis) shows a contribution of financial controlling presented with a 3-step scale. 


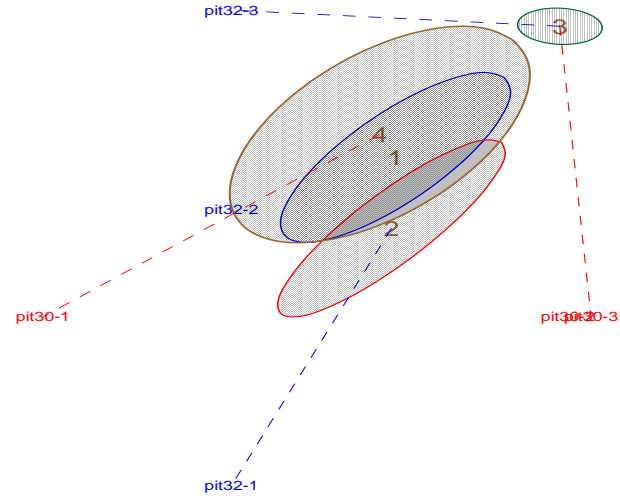

Figure 2. Elipse of activities of respondents in relation to the importance of the interaction between managers and financial controllers and contribution of financial controlling. Legend: services (1); banking (2); insurance (3); trade (4); I completely disagree; I partly agree.

By looking at Figure 2. it can be noticed that in the importance of interaction between managers and financial controllers and the contribution of financial controlling, the ellipses of business activity Services (1) and Trade (4) overlap or have similar characteristics.

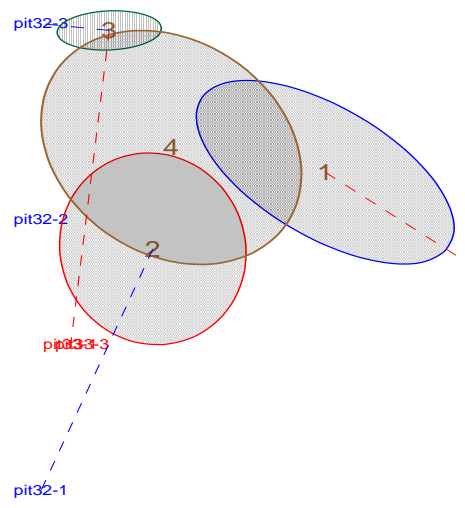

Figure 3. Elipse of activities of respondents in relation to the importance of the rewards and motivation and financial controllers and contribution of financial controlling.

Apscisa (horizontal axis) shows the importance of reward and motivation presented with a 3-step scale, and the ordinate (vertical axis) shows a contribution of financial controlling, which is represented by a 3-step scale. Figure 3. shows the relation between activities in relation to the importance of reward and motivation and in relation to the contribution of financial controlling.

In Republic of Serbia, insurance companies are usually large companies, especially companies included in the analysis. They have to cooperate with all sectors and branches in the planning and control process. The plan must start from the procurement process to the ultimate goal of selling [9]. Only in this way can the exact goals of the company be determined to develop a strategy. A well-developed strategy provides a well-defined budget for each project and sector, in which case the deviations should be minimal [10]. This whole process is primarily significant in order to reduce operating costs, in the future it is expected that these costs will increase constantly, as they are increasingly burdened with the marketing costs of promotion, maintenance costs of the information system, and other costs that are a bit high, because it is about really big financial institutions.

\section{CONCLUSION}

After statistical analysis of collected data on the observed sample and obtained research results, we can conclude that the application of the adequate model of financial controlling is most effective in insurance companies. We can also draw more practical recommendations for better management of business results that can be linked to the results of the research:

1. to create and improve the organization of the business development plan. Namely, the coordination and the process of developing a business plan are given the slightest importance, which in turn affects to the quality and timing of the development of the plan; to introduce systematic preparations and coordination of planned activities by products or services, customers and organizational units;

2. for better planning to ensure respect for attitudes of lower organizational units; planning is usually implemented "top-down" in practice, and to a lesser extent the attitudes of lower organizational units are respected; in this way, better communication will be achieved in the relationship between managers and employees;

3. to enable the introduction of permanent, systematic, selective and timely notification to all decision makers in the insurance company about established deviations from the plans, their consequences and possible measures for their removal and for the audit of the control system;

4. to use comprehensive information (eg Big data concept) in the planning process; for business success, 
it is necessary to start from the market, through the company to the products or services, because in our business practice the approach to "internal data" predominantly prevails;

5. to establish a link between strategic and individual objectives; a space for business effectiveness can be opened when infrastructure is prepared in an efficient way and supports the achievement of goals;

6. to analyze the overall internal and external environment, in addition to the financial statements; along with "traditional" instruments it is necessary to introduce and use additional instruments for analysis: comparing the realization and the plan, we answer to questions about who, when and how much, and other analyzes we can answer and why;

7. to plan and monitor business through a multidimensional and dynamic view, due to dynamic business conditions, in order to manage the causes rather than the consequences. Standard financial reports provide continuity in reporting, and dynamic reports can provide answers about the reasons for individual movements;

8. it is also necessary to provide non-financial information in managerial reports, in addition to financial. Financial information generally includes the quantification of business processes, while nonfinancial ones often deal with the causes of appropriate changes and processes;

9. the introduction of an appropriate information system for the continuous collection of data and information, necessary for the accomplishment of controlling tasks.

The research has shown that most insurance companies in Serbia have established function and processes of controlling. Through cooperation with management, the financial controlling can significantly contribute to achieving better business results. Insurance companies have largely recognized the benefits that they can have from a well-organized function and process of financial controlling. In practice, in different insurance companies there is a different level of development and quality of controlling. In an adequately organized manner of financial controlling, and controlling in general, for example, organizing calendar of controlling activities, can contribute to better corporate governance.

\section{REFERENCES:}

[1] Deyhle, A., Kottbauer, M., Pasher, D. (2010), Manager und Controlling, Verlag für Controlling Wissen, Freiburg
[2] Deyhle, A., Eiselmayer, K., (2007), Controller \& Controlling, Verlag - Controller Akademie, München.

[3] International Group of Controlling, IGC, (2005), Controller Wörterbuch, Verlag - Schäffer - Poeschel, Stuttgart

[4] Eiselmayer, K., Pascher, D., Perovic V. (2014), Financial controlling, Verlag für Controlling Wissen, Freiburg

[5] Horváth, P., (2009), Das Controlling konzept, 11. Auflage, Verlag - Franz Vahlen Beck, München

[6] Horváth, P., Gleich., R., (2007), Controlling umsetzen, Verlag Schäffer-Poeschel, Stuttgart

[7] Kück, U., (2009), Schnelleinstieg Controlling, Verlag - Haufe, München

[8] Kuzmanović, T. Kuzmanović, B.:(2008) Estimate of incurred but not reported claims (IBNR) by Chain- Ladder method and the influence at solvency of insurance companies, XIV International scientific conference on industrial systems, Novi Sad.

[9] Kuzmanović, B. Kuzmanović, T.: (2008), Osiguranje kao podrška u razvoju kompetitivnog sela, Fakultet tehničkih nauka monografija, Novi Sad.

[10] Kuzmanović, B., Stankov, B., Kuzmanović, T., (2011), The application of fuzzy model in the assesment of the maintenance function in insurance manufacturing system, XV International scientific conference on industrial systems, Novi Sad.

[11] Živkov, E., Nerandžić, B., Kuzmanović, B., (2015), „A Correlation Between the Function of Controlling and the Process of Risk Management in the Company", International Journal of Industrial Engineering and Management, Vol. 6, No. 4, pp. 179-189

[12] Perović, V., (2007), Kontroling, Rodacomm, Novi Sad

[13] Perović V., Nerandžić B., Todorovic, A., (2012), Controlling as a useuful managament instrument in crisis times, African Journal of Business Management, Vol.6 (6), pp. 2101-2106

[14] Perovic, V., Bojanic, R., Nerandzic, B. (2017), Measuring efficiency of teaching process and faculty in transition states using DEA analysis. Tehnički vjesnik, 24 (5), pp. 1509-1517

[15] Perović, V., (2004), Controlling of an enterprise,

[16] Privredna izgradnja, Novi Sad, No1-2

[17] Perović, V., (2007) What is Controlling?, University of economics in Bratislava, 11thInternational Scientific Conference, AIESA, Bratislava, May 17th - 18th 2007.

[18] Perović, V., (2007), Controlling philosophy, Faculty of economics Belgrade, International Scientific Conference, Belgrade 26th 29th Septembre 2007.

[19] Perović V., Vujičić M., (2015) Controlling: between theory and practice, International Journal of Industrial Engineering and Management - IJIEM, Vol. 6, No 4-2015, pp. 165-170, ISSN: 2217-2661.

[20] Volker S., (2010), Basiswisen Controlling , Verlag - Beck München

[21] Weber, J., (2008), Einführung in das Controlling, Verlag Schäffer-Poeschel, Stuttgart

[22] www.controllingakademie.de

[23] www.mycontrolling.de

[24] www.fei.org 


\section{Značaj finansijskog kontrolinga u uslužnom sektoru sa osvrtom na osiguranje}

Tatjana Kuzmanović

Primljen (28.12.2018.); Recenziran (22.01.2019.); Prihvaćen (13.02.2019.)

\section{Abstrakt}

Finansijski kontroling je značajna funkcija podrške menadžmentu u upravljanju poslovnim procesima i poslovnim rezultatom. U uslovima sve jače konkurencije u poslovanju, neophodno je da se delatnost u uslužnim sistemima odvija s najmanjim mogućim troškovima uz najveće moguće zadovoljstvo zaposlenih i poslovnih saradnika. To se može postići postavljanjem jasne strukture kontrole troškova poslovanja. S jedne strane, to je preduslov da preveliko smanjenje troškova ne dovede u opasnost samu delatnost, a $s$ druge strane, time se sprečava da trošenje bez kontrole dovede do gubitka u poslovanju. Poređenje planiranih i ostvarenih prihoda temelj je odlučivanja o daljem poslovanju. To su osnovni postulati finansijskog kontrolinga.

Ključne reči: finansijski kontroling, poslovni rezultat, uslužni sistem 